\title{
The Role of Women in Improving Reproductive Health in Indonesia
}

\author{
Alifiulahtin Utaminingsih ${ }^{1}$, Nestiana Jelita ${ }^{2}$ \\ \{alifiulathin@ub.ac.id ${ }^{1}$,jelitanestian@gmail.com² \\ Universitas Brawijaya, Indonesia ${ }^{1,2}$
}

\begin{abstract}
This study is important because reproductive health is not achieved in many countries, include Indonesia, this is one of the conclusions of the world conference. as individuals who have autonomy to control their body and sexuality and have the right to enjoy the highest standards of health both physically, psychologically and socially, protected by the State. Women are often in a state of being oppressed and exploited so that oppression and exploitation of women and violence against women in various forms (domestic violence, sexual violence including marital rape, rape, trafficking of women or girls, exploitation of prostitution) must end, and in increasing the role of women in reproductive health women must enter the public sector, increase women's knowledge about reproductive health and awareness women will be oppressed both physically and mentally. Feminism is an understanding that wants to respect women so that their rights and roles are more optimal and equal, there is no discrimination, marginalization and subordination. Reproductive rights and reproductive health become very important issues to be addressed, because it involves issues of women's human rights.
\end{abstract}

Keywords: Reproductive Health, The Role of Women.

\section{Introduction}

Reproductive health is not achieved in many countries, include Indonesia, this is one of the conclusions of the results of the World Population Conference held in Cairo in 1994 [1], while the contributing factors are as follows: 1) insufficient level of knowledge about sexuality as well as reproductive health information and services that are incorrect or of less value; 2) the prevalence of high-risk sexual behavior; discriminatory social practices; 3 ) negative attitudes towards women and girls; and the limited power possessed by many women and girls over their sexual and reproductive lives. So, far the Indonesian government has only looked at the issue of human sexuality and reproduction in the interests of population-control power to be economically and politically effective. Specifically, it controls women's "fertility" bodies (example: family planning programs that place women as objects).

On the contrary, the humanism and human rights approach in looking at population and development matters, places humans (men and women) as individuals who have autonomy to control their body and sexuality and have the right to enjoy the highest standards of health both physically, psychologically and social, protected by the state [2]. One indisputable fact is that teenagers often get information about sexuality and reproduction precisely from their friends, partial information in the mass media, and in books, which sometimes the information cannot be ascertained. In fact, for adolescents, the right to information and access to services 
is the primary reproductive health right. Because the needs for information about functions, systems and processes of reproduction, are closely related to themselves, and will have a significant social impact in socializing among their peers or the community at large [3].

\section{Research Methods}

This study uses a qualitative-descriptive method to explain and analyze a phenomenon of women are often in a state of being oppressed and exploited so that oppression and exploitation of women and violence against women in various forms (domestic violence, sexual violence including marital rape, rape, trafficking of women or girls, exploitation of prostitution) must end, and in increasing the role of women in reproductive health women must enter the public sector, increase women's knowledge about reproductive health and awareness women will be oppressed both physically and mentally.

Bogdan and Taylor explained that descriptive methods a research procedure that produce data in the form of written or oral words from people and observable behavior. The data are obtained as of interviews, photos, personal documents, observations and other official documents [4].

\section{Results and Discussion}

\subsection{Gender and Reproductive Health}

The focus of differences in the rights of women and men due to sex or biological, is actually due to a patriarchal system (the system of power that exists in society and family) that has been prescribed in customs and habits. A feminist Stone, argued that the oppression of women because of social relations in the process of reproduction rather than social relations in the production process, which tends to make these relationships into exploitative relationships. A feminist Heidi Hartman (Socialist Feminist) in her book "The Unhappy Marriage of Marxist and Feminism" which analyzes women's rights through two different approaches, namely: Dual System Theory and Unified System Theory. Capitalism as a material or historical structure is rooted in the mode of production, namely the way in which production activities are carried out, Shulamith Firestone: "The Dialectic of Sex" while patriarchy is historically rooted in the mode of reproduction/sexuality, the way in which the process of reproduction or sexuality is carried out. Other writers about Dual Systems describe patriarchy as a nonmaterial structure, namely an ideological structure and or a psychoanalytic structure. While the Unified System Theory (Irish Young and Alian Jagar), analyzes capitalism and patriarchy together using one concept [5].

The concept is the sexual division of labor which is considered capable of accommodating Marxist, radical feminist and psychoanalytic views. While other authors, Alison Jaggar, used the concept of alienation and assumed that this concept was quite capable of accommodating the views of the three perspectives. Tong, who explores some feminist perspectives and considers this theory ambitious in comparison to the Dual System Theory. Awareness of women about their reproduction needs to be given some more specific meaning, namely what is called rights, health and reproduction itself, namely: rights are inherent authority to do or not do, obtain or not obtain something. Awareness of the rights as a human being and as a 
woman as a power for women to carry out various activities for self, family and community interests. Healthy is not only Hidayati who cites Juliet Mitchell's writings in her book "Women's Estate and Psychology and Feminism", the author of this concept is Irish Young in his book, "Beyond the Unhappy Marriage", quoted by Hidayati, Jaggar's writings on, "Feminist Politics and Humanism Nature", as quoted by Hidayati, is related to physical, but also mental and social discomfort, these three aspects are related to each other and influence each other, which can make a person sick or healthy [6].

Reproduction is reproducing or the ability of women to produce offspring repeatedly. From the definition above, the meaning of reproductive health rights becomes a series of words that have a vision, mission and program, that reproductive health rights and health are two concepts that are not limited to medical problems of reproductive organs. The first concept is reproductive rights, the second is reproductive health. The 4th World Conference on women defines reproductive health as a state of complete physical, mental and social wellbeing, not just the prevention of disease or weakness, which is related to the reproductive system, its functions and processes.

Such a definition, is actually also not much different from the understanding of health introduced by Article 1 (1) of Law Number 23 of 1992 concerning Health, although in the Health Act, is more general, and no specific definition of reproductive health will be found. This law has been revised with Law Number 36 of 2009 concerning Health, interpreting reproductive health is a state of physical health, mental, and social as a whole, not Sri Rahayu and Abdul Jalil, Reproductive Health Rights, Definition, Objectives, Problems and Factors Inhibition, Quoted from the implication of the ICPD (International Congress Population and Development) program of action, 1994. The Beijing Declaration, as an important document resulting from the 4th World Conference on Women, 4-15 September 1995 in China is solely free of disease or disability associated with systems, functions, and the process of reproduction in men and women. Reproductive health as referred to in paragraph (1) includes: a) before pregnancy, pregnancy, childbirth, and after childbirth; b) pregnancy regulation, contraception tools, and sexual health; and c) reproductive system health. Reproductive rights, which are meant in the Beijing Declaration, include certain human rights that have been recognized in national law, international documents on human rights and other consensus documents. Specifically the Beijing Declaration gives serious attention to adolescents, mandating the fulfillment of education and services regarding reproductive health so as to enable adolescents to handle their sexuality in a positive and responsible manner [7].

The main factors that cause the non-fulfillment of reproductive rights are due to a lack of knowledge about sexuality, limited information about reproductive health and inaccessibility to access to reproductive health services, in addition to inadequate services, as well as negative attitudes towards girls and of course discriminatory actions against them. In the 1999 World Women's Conference, it was reiterated that women's human rights are "including the right of women to have free and responsible control and decisions on issues relating to their sexuality, including the health of Law Number 36 of 2009 concerning Health, Article 71, Paragraph (2). Reproductive and sexual, free from coercion, discrimination and violence. The same relationship between men and women with regard to sexual and reproductive relations, the same respect and agreement, and mutual responsibility for sexual behavior and its consequences "Likewise in the United Nations Convention on the Elimination of All Forms of Discrimination against Women (CEDAW), which has been ratified by the Government of Indonesia through Law Number 7 of 1984. That "Discrimination against women is any distinction, exclusion, restriction that has a purpose or influence which will reduce or 
eliminate the recognition, enjoyment or use of human rights for/by women, regardless of their marital status" (Article 1).

Efforts that have been made by women's groups to broaden recognition of women's reproductive rights include: Fighting for the birth of Law Number 23 of 2004 concerning the Elimination of Domestic Violence (including sexual violence in the household as a criminal act). Protection of women and girls from trafficking practices (including prostitution and sexual exploitation as a mode and purpose of trafficking) in Law Number 21 of 2007. Efforts to amend Law Number 1 of 1974, mainly to remove provisions concerning the domestication of women, polygamy, the marriage age limit for girls. Reproductive health is a state of complete physical, mental and social well-being, and is not only marked by the absence of disease or the Beijing Declaration, Platform for Action, 1999. Weaknesses, in all matters relating to the reproductive system and its functions and processes [8].

Therefore, reproductive health also means that a person can have a safe and satisfying sexual life and that they have the ability to reproduce and the freedom to determine whether they want to do it, when and how often. Included in this latter circumstance are the rights of men and women to obtain information and have access to safe, effective, affordable and acceptable family planning methods, which they choose, as well as other methods they choose to regulate fertility that are not against the law; and the right to obtain appropriate health care services, which will enable women to safely undergo pregnancy and childbirth; and provide the best opportunities for couples to have healthy babies.

Reproductive health also includes sexual health, which aims to improve the status of life and personal relationships, not solely counseling and care related to reproduction and sexually transmitted diseases. That what is meant by reproductive health is [9]:

a) Physical and mental well-being as a whole;

b) All matters relating to the reproductive system and its functions

c) Have a satisfying and safe sex life;

d) Having the ability to reproduce and the freedom to determine whether they want to do it, when and how often;

e) Have access to safe, effective, affordable and acceptable ways of family planning that are their choice and the methods they choose;

f) The right to obtain appropriate health care services, which enable women to survive pregnancy and childbirth.

g) Provide the best opportunity for couples to choose healthy babies.

In view of this formulation, reproductive rights include certain human rights that have been recognized in national laws, international human rights documents, and other relevant United Nations consensus documents. These rights are based on the recognition of the basic rights of all partners and individuals to determine freely and responsibly the number of children, detention of children and determine the time of birth of their children and have information and ways to obtain it, as well as the right to achieve standards highest sexual and reproductive health. This also includes the right of all people to make decisions about reproduction free from discrimination, coercion and violence as stated in human rights documents.

The social construction (of sexuality) that exists in patriarchal societies everywhere has alienated women from their ability to control their bodies and sexuality, including their reproductive health. The phenomenon of violence against women in various forms is one form (domestic violence, sexual violence including marital rape, rape, trafficking of women or girls, exploitation of prostitution) occurs in almost all corners of the world [10]. 


\section{Conclusion}

Health development aimed at increasing the level of public health. For the sake of achieving a high degree of health, women as health recipients, family members and health care providers must play a role in the family, so that children grow up to adulthood as young people. Reproductive health services are needed to meet the health needs of women and men related to issues of sexuality and pregnancy spacing. The objectives of the related programs and configuration of the services must be comprehensive, and refer to conventional Family Planning (Keluarga Berencana) programs and maternal and child health services. Components included in reproductive health are:

a) Counseling about sexuality, pregnancy, contraception, infertility abortion, infection and disease.

b) Sexuality and gender education.

c) Prevention, screening and treatment of reproductive tract infections, sexually transmitted diseases (STDs), including HIV/AIDS and other obstetric problems.

d) Providing correct information so that you voluntarily choose an existing contraceptive method.

e) Prevention and treatment of infertility.

f) Safe abortion services.

g) Services for pregnancy, childbirth by health workers, postnatal services.

h) Health services for babies and children.

The oppression of women comes from class exploitation and production, the human need to maintain their lives is carried out by all members of the family including women. The result of this is a sexual division of labor. Thus, one way to free women from family injustice is:

a) Women must enter the public sector which can produce economic value so that the concept of women's domestic work no longer exists.

b) Non-fulfillment of adolescent reproductive rights is due to a lack of knowledge about sexuality, limited information about reproductive health and the inaccessibility of adolescents to access to reproductive health services, in addition to inadequate services, as well as negative attitudes towards girls and of course discriminatory actions against them. Many things that women can do to improve the understanding of adolescents in their environment regarding reproductive health include providing counseling on reproductive health routinely and periodically to provide appropriate information to adolescents, so that adolescents do not seek and obtain false and partial information about reproductive health. Understanding of reproductive health for adolescents is a right regulated in the law so that it is our duty to provide appropriate information to them.

c) Awareness of women of their oppressed position both physically and mentally towards women in society, Because, many women are not aware of the oppression, it is necessary for men's participation to change the community's view of equality.

In Indonesia, the issue of health policy has come to the attention of the women's movement. The issue of maternal mortality for example is the focus of attention of the women's movement. But until now it is still a problem that has never been resolved. Women's health is also related to the position of women as subjects. Especially in the case of reproductive health knowledge about sexual and reproductive health and rights determines not only the physical condition of women but also women's well-being.

A number of studies in women's journals show that the values and cultural elements that live in society have a strong influence on people's beliefs, decisions, attitudes, and behaviors regarding women's health. In addition, the experience of women dealing with health issues 
should not be viewed equally and universally. All of these aspects need to be well understood by policy makers and health workers so that health policies and health services truly take into account the voices and needs of women. Health policies and services should position women as subjects who are entitled to make decisions regarding their health.

Life as a woman in Indonesia is not an easy thing. The social system in the community has resulted in women living with all vulnerabilities, including those that can cause death. Community's perception in seeing women as objects. That way the existing policies are not enough to exclude women from these vulnerable conditions. One of the vulnerabilities experienced by women is when women are in the cycle of pregnancy, giving birth. Unsupportive cultural conditions and inadequate health facilities make women even more vulnerable.

The problem of Maternal and Child Mortality $(\mathrm{MCH})$ is a problem that cannot be separated from the culture or behavior of the community itself. Cultural factors of a society have given birth to concepts of thought in the community one of which is related to health problems. The health conditions of a community, especially those related to women's reproductive health cannot be seen in terms of health services and facilities. Described from the results of research on cultural elements that influence people's behavior and perspectives.

\section{References}

[1] The Beijing Declaration, as an important document resulting from the 4th World Conference on Women, 4-15 September 1995 in China.

[2] Results of the World Population Conference in Cairo 1994. http://majalahtantri.wordpress.com Irish Young "Beyond the Unhappy Marriage". Jaggar about, "Feminist Politics and Human Nature". Juliet Mitchell "Women's Estate and Psychology and Feminism. .

[3] "No Title." [Online]. Available: http://journal.uinjkt.ac.id/index.php/psga/article/view/10403.

[4] L. J. Moleong, Metodologi Penelitian Kualitatif. Bandung: Remaja Rosdakarya, 2000.

[5] "No Title." [Online]. Available: https://www.researchgate.net/publication/2938 21955_FEMINISME_SEBAGAI_TEORI_DAN_GERAKAN_SOSIAL_DI_INDONESIA.

[6] Irish Y' Young "Beyond the Unhappy Marriage". Jaggar about, "Feminist Politics and Human Nature". Juliet Mitchell "Women's Estate and Psychology and Feminism. .

[7] "No Title." [Online]. Available: http://majalahtantri.wordpress.com/2010/01/27/m realize-hakperempuan-atas-diri.

[8] "No Title." [Online]. Available: reproductive-health-and-sexual-as-ham\%25 E2\%25 80\%25 9D. [Accessed: 28-Feb-2011].

[9] S. Rahayu and A. Jalil, Reproductive Health Rights, Definition, Objectives, Problems and Inhibiting Factors. UU no. 36 of 2009 concerning. .

[10] A. Utaminingsih, Gender dan Wanita Karir. Universitas Brawijaya Press, 2017. 